\title{
Pemodelan Homologi Protein Receptor Orphan Receptor-1 (ROR-1) Sebagai Target Terapi Chronic Lymphocytic Leukemia (CLL)
}

\author{
Ruslin, Suci Rahmawati Putri, Muhammad Arba \\ Fakultas Farmasi Universitas Halu Oleo, Kampus Hijau Bumi Tridharma Anduonohu, Jl. H. E. A. Mokodompit Kendari 93232 \\ E-mail: mahaleo241@yahoo.co.id
}

\begin{abstract}
Receptor Orphan Reseptor-1 (ROR-1) is a trans-membrane protein consists of 937 amino acid residues located on $1 \mathrm{p} 31.3$ chomosome. ROR-1 has an important role in leukemogenesis of CLL cells. Co-expressions of ROR-1 and TCL enhance leukemogenesis and caused AKT's phosphorylation, cell's proliferations, and resistances to apoptosis. This study had done physicochemical characteristics analysis, secondary structure and tertiary structure prediction of ROR-1 Protein using few types of bioinformation tools. The physicochemical characteristics analysis was done by using Expasy Protparam server and the prediction of secondary structure was using Sopma and Psipred. The prediction of ROR-1's tertiary structure was done by using Modeller 9.19 software and resulting five ROR-1's tertiary structures predicted model. The accuration of the results then evaluated using Ramachandran's plot analysis and it was showed Model 3 is the best models wich percentage is $82 \%$.
\end{abstract}

Keywords: ROR-1, Choronic Lymphocytic Leukemia (CLL), homology modeling, Modeller, Ramachandran plot

\section{Pendahuluan}

Leukemia atau kanker darah adalah penyakit keganasan sel darah yang berasal dari sumsum tulang ditandai dengan proliferasi sel-sel darah putih, oleh adanya sel-sel abnormal yang diproduksi secara tak normal (transformasi maligna) dari sel-sel pembentuk darah di sumsum tulang dan jaringan limfoid [1]. Leukemia termasuk ke dalam jenis tumor cair (liquid tumor) [2]. Leukemia ditandai oleh penimbunan sel darah putih yang abnormal dalam sumsum tulang, yang dapat menyebabkan kegagalan sumsum tulang dan meningkatnya sirkulasi sel darah putih [3].

Chronic Lymphocytic Leukemia (CLL) merupakan keganasan hematologi yang ditandai akumulasi limfosit kecil matang dalam darah, sumsum tulang dan jaringan limfoid. Resiko terjadinya penyakit ini meningkat dengan bertambahnya usia, dan lebih sering dijumpai pada laki-laki dibandingkan dengan wanita [4]. Data statistik kanker Surveillance, Epidemiology, and End Result Program National Cancer Institute prevalensi leukemia sebesar 13,7 per 100.000 populasi per tahun, dan jumlah kematian leukemia sebesar 6.8 per 100.000 populasi per tahun. Leukemia berada di urutan ke-9 dilihat dari prevalensi kejadiannya, yaitu sebesar 3.7\% dari seluruh kanker. [5]. Pilihan obat yang digunakan untuk pengobatan CLL adalah Fludarabine di kombinasi dengan senyawa berbeda seperti siklofosfamid dan anti-CD20 mAbs telah meningkatkan efisiensi dan efektivitas pengobatan. Akan tetapi, obat ini hanya efektif untuk pengendalian penyakit bukan untuk terapi [6]. Banyak usaha yang telah dilakukan untuk mengatasi kekurangan terapi CLL saat ini. Banyak peneliti telah mencoba menyajikan modalitas baru untuk terapi CLL menggunakan pendekatan berbeda termasuk mAbs spesifik, inhibitor tyrosine kinase, imunotoksin, dan terapi sel[7]. Semua modilitas berpotensi terapeutik terutama protein ROR-1 ditargetkan untuk terapi CLL [8].

Reseptor Orphan Reseptor-1 (ROR-1) adalah protein transmembran yang terdiri dari 937 residu asam amino. ROR-1 terletak pada kromosom 1p31.3[9]. ROR-1 juga memiliki peran dalam leukemogenesis dari sel CLL dengan berinteraksi pada sel $\mathrm{T}$ antigen leukemia yang merupakan aktivator dari AKT. Ko-ekspresi dari ROR-1 dan TCL 1 meningkatkan leukemogenensis sehingga terjadi fosforilasi AKT proliferasi sel dan resisten terhadap apoptosis [10]. Fosforilasi ROR-1 residu tirosin pertama dan terakhir sangat penting. ROR-1 secara konstitutif terfosforilasi residu tirosin pada sel Chronic Lymphocytic Leukemia (CLL), Anti-ROR-1 mAbs melawan Domain CRD dan KNG menginduksi defosforilasi ROR-1 di residu tyrosine diikuti oleh apoptosis sel leukemia[11].

Berdasarkan profil ekspresi pengujian ROR-1 dilakukan secara praklinis pada kelinci fab khusus untuk ROR-1 sebagai target baru untuk terapi CLL. Hasil penelitian yang dilakukan menunjukkan bahwa ROR-1 secara kolektif dapat mengikat molekul pada manusia dan mengaktifkan antibody-dependent cell-mediated cytotoxicity (AADC), complement mediated cytotoxicity (CDC) serta induksi apoptosis sel pada CLL dimana ekspresi yang kuat dari ROR-1 dapat terlihat pada sel-B CLL [12]. Terapi kanker pada sel target muncul sebagai pilihan pengobatan baru untuk berbagai jenis kanker. Salah 
satu pendekatan yang dapat dilakukan untuk menemukan obat yang selektif membunuh sel kanker yaitu dengan mengenali atau mengetahui karakterisasi protein-protein yang bekerja pada sistem regulasi penyakit kanker[13]. Struktur protein diprediksi dengan metode pemodelan homologi (homology modeling) [14]. Sulitnya menentukan struktur dan terbatasnya kemampuan untuk melakukan penelitian secara langsung di dalam laboratorium, maka menyamakan atau membuat pemodelan homologi (homology modeling) dapat dijadikan sebagai cara untuk menentukan struktur tersier menggunakan sekuens protein yang telah diketahui (target) terhadap pensejajaran sekuens (alignment) dari satu atau lebih pola struktur protein yang telah diketahui (pola/template) [15].

Berdasarkan hal tersebut, perlu dilakukannya penelitian untuk mencari struktur tersier protein Receptor Orphan Receptor-1 (ROR-1) melalui program modelling komputer Modeller. Kemudian akan dilakukan validasi terhadap struktur tersier protein Receptor Orphan Receptor-1 (ROR-1) karena dengan mengetahui struktur tersier protein ROR-1, bisa dijadikan sebagai acuan untuk memperkirakan bentuk senyawa yang dapat berinteraksi dengan protein tersebut pada tingkat molekuler sehingga memudahkan pencarian senyawa obat yang dapat berpotensi sebagai target terapi Chronic Lymphocytic Leukemia (CLL).

\section{Metode Penelitian}

\subsection{Umum}

Alat yang digunakan dalam penelitian yakni Perangkat Keras (Hardware) Laptop dengan spesifikasi Intel-CoreTM i5-8250U (3.4 GHz) NVIDIA ${ }^{\circledR}$ GeForce ${ }^{\circledR}$ (4GB VRAM) 4GB DDR3 L Memory 1TB HDD, Sistem operasi: Windows ${ }^{\circledR}$, serta software Modeller v9.18 dan software PyMol v1.8.6.0. Sekuens protein ROR-1 Homosapiens yang diperoleh dari National Center of Biotechnology Information (NCBI).

\subsection{Pemastian Struktur ROR-1 dan Analisis Fisikokimia}

Penelitian ini dilakukan untuk membangun struktur tersier dari suatu protein yang belum diketahui sturktur tersier sebelumnya. Untuk memastikan apakah protein ROR-1 belum memiliki struktur tersier adalah dengan melakukan pencarian pada server PDB. Analisis sifat fisikokimia berdasarkan struktur primer protein ROR-1 dilakukan menggunakan server Expasy ProtParam, yang meliputi beberapa parameter fisikokimia berupa titik isoelektrik teoritis (pI), berat molekul, komposisi asam amino, perkiraan waktu paruh, rata-rata nilai hidropati (GRAVY), indeks alifatik dan indeks ketidakstabilan.

\subsection{Prediksi Struktur Sekunder}

Struktur sekunder protein ROR-1 diprediksi dengan menggunakan server SOPMA dan PSIPRED. Server tersebut memperkirakan sifat struktural sekunder seperti ahelix, Pi helix, beta bridge, extended strand, bend region, beta turns, random coil, dan ambiguos states.

\subsection{Prediksi Struktur Tersier}

Struktur tersier protein ROR-1 diprediksi dengan menggunakan software Modeller yang dimulai dengan pencarian struktur protein yang homolog (template) dengan protein target ROR-1 menggunakan analisis BLAST. Analisis tersebut akan menghasilkan berbagai macam protein yang memiliki kemiripan dengan ROR-1. Tahap selanjutnya yaitu mensejajarkan target dengan template dengan cara mensejajarkan residu-residu asam amino antara sekuens asam amino ROR-1 dengan sekuens asam amino template. Setelah penyejajaran target-template telah dibuat, Modeller akan secara otomatis membangun model target menggunakan kelas automodel.

\subsection{Validasi Struktur}

Hasil kelima pemodelan struktur tersier ROR-1 divalidasi menggunakan server PROCHECK untuk memeriksa kualitas streokimia dan stabilitas model dari struktur protein berdasarkan plot Ramachandran.

\section{Hasil dan Pembahasan}

Hasil pencarian struktur protein ROR-1 pada server PDB menunjukkan bahwa ROR-1 belum memiliki struktur tersier. PDB merupakan satu-satunya gudang informasi global tentang struktur tiga dimensi yang meliputi struktur tersier ataupun struktur kuarterner molekul biologis dari protein maupun asam nukleat.

\subsection{Analisis Sifat Fisikokimia}

Analisis struktur primer atau urutan asam amino memberikan wawasan mengenai struktur protein, sehingga dapat memberikan kemudahan dalam memahami fungsi biokimia maupun fungsi seluler [16]. Hasil analisis sifat fisikokimia diantaranya berupa komposisi asam amino penyusun protein ROR-1 dapat dijadikan sebagai acuan dalam menentukan sifat fisiko-kimia protein ROR-1, serta nilai dari beberapa parameter fisikokimia protein ROR-1.

Berdasarkan Tabel 1 terlihat jenis asam amino yang paling mendominasi dalam menyusun protein ROR-1 adalah serin sebanyak 93 asam amino $(9,9 \%)$ dan prolin sebanyak 79 asam amino (8,4\%). Kompisisi asam amino ini dapat menjadi acuan dalam proses pembentukkan atau pelipatan suatu struktur sekunder dan tersier protein ROR1. Namun komposisi suatu asam amino tidak dapat memberikan nilai rinci dari parameter sifat fisikokimia protein ROR-1.

Hasil analisis fisikokimia menggunakan server ProtParam Expasy menunjukkan ROR-1 memiliki berat molekul sebesar 104282.62 Da, berat molekul protein melalui server ProtParam Expasy dihitung dengan penambahan massa isotop rata-rata asam amino dalam protein yang disediakan dan massa isotop rata-rata dari satu molekul air. Perkiraan waktu paruh ROR-1 pada mamalia retikulosit secara in vitro adalah 30 jam, ragi secara in vivo $>20$ jam dan Escherichia coli secara in vivo $>10$ jam. Waktu paruh adalah prediksi waktu yang diperlukan setengah dari jumlah protein dalam sel untuk menghilang setelah 
sintesisnya di dalam sel [17]. Waktu paruh berkaitan dengan waktu yang dibutuhkan untuk mengganti setengah dari molekul protein. Informasi mengenai waktu paruh atau tingkat degradasi terhadap suatu protein dapat digunakan sebagai acuan dalam pengembangan obat dalam berbagai jenis penyakit. Sehingga dikarenakan protein ROR-1 menjadi target terapi kanker Choronic Lymphocytic Leuekemia (CLL), maka senyawa obat yang akan berinteraksi dalam menghambat kerja ROR-1 harus dipastikan dapat mencapai target dalam kurun waktu 30 jam.

Tabel 1. Komposisi asam amino ROR-1

\begin{tabular}{lcc}
\hline \multicolumn{1}{c}{ Asam Amino } & Jumlah & Komposisi \\
\hline Alanin (A) & 58 & $6.2 \%$ \\
Arginin (R) & 46 & $4,9 \%$ \\
Asparagin (N) & 45 & $4.8 \%$ \\
Aspartat (D) & 36 & $3.8 \%$ \\
Cystein (C) & 28 & $3.0 \%$ \\
Glutamin (Q) & 43 & $4,6 \%$ \\
Glutamat (E) & 53 & $5,7 \%$ \\
Glisin (G) & 58 & $6,2 \%$ \\
Histidin (H) & 30 & $3,2 \%$ \\
Ileusin (I) & 57 & $6,1 \%$ \\
Leusin (L) & 77 & $8,2 \%$ \\
Lisin (K) & 39 & $4,2 \%$ \\
Metionin (M) & 26 & $2,8 \%$ \\
Fenilalanin (F) & 37 & $3,9 \%$ \\
Prolin (P) & 79 & $8,4 \%$ \\
Serin (S) & 93 & $9,9 \%$ \\
Treonin (T) & 47 & $5,0 \%$ \\
Triptofan (W) & 10 & $1,1 \%$ \\
Tirosin (Y) & 34 & $3,6 \%$ \\
Valin (V) & 41 & $4,4 \%$ \\
\hline
\end{tabular}

Nilai pI (isoelectric point) teoritis ROR-1 sebesar 6,76 yang adalah nilai $\mathrm{pH}$ dimana total muatan gugus bermuatan positif dan negatif mencapai kestabilan (sehingga total muatan asam amino tersebut adalah nol) [18]. Apabila $\mathrm{pH}$ berada diatas titik isoelektrik protein bermuatan negatif, sedangkan dibawah titik isoelektrik maka protein bermuatan positif. Titik isoelektrik merupakan data yang sangat penting diketahui untuk proses pemurnian suatu protein. Jika titik isoelektrik (pI) sutu protein sudah diketahui maka strategi awal pemisahan dapat dengan mudah dikembangkan.

GRAVY (grand average of hydropathicity) hidropatik atau rata-rata hidropatik merupakan parameter yang menentukan sifat hidrofobik suatu protein, apabila nilai indeks hidropati asam amino semakin positif, semakin hidrofobik asam amino tersebut [19]. Hasil analisis menunjukkan bahwa nilai GRAVY dari protein ROR-1 adalah -0,359 yang menunjukkan bahwa protein ROR-1 bersifat hidrofilik. Hal ini sangat berpengaruh terhadap proses pelipatan suatu asam amino dalam pembentukan struktur tersiernya. Diketahui bahwa protein yang kaya akan residu asam amino yang bersifat hidrofilik sulit membentuk lipatan menjadi stuktur tersier yang baik.

Protein ROR-1 memiliki indeks kestabilan sebesar 54,10 . Indeks ketidakstabilan adalah ukuran protein yang memberikan perkiraan stabilitas suatu protein. Sebuah protein yang indeks ketidakstabilannya lebih kecil dari 40 diprediksi stabil, jika lebih besar maka kemungkinan tidak stabil [20]. Berdasarkan hasil yang diperoleh menunjukkan bahwa protein ROR-1 merupakan protein yang tidak stabil. Hal ini akan berpengaruh terhadap proses pembentukkan dari struktur tersier protein ROR-1.

Indeks alifatik merupakan volume relatif yang ditempati oleh asam amino seperti alanin, valin, isoleusin dan leusin, yang memiliki rantai samping alifatik dalam strukturnya dan dianggap sebagai faktor yang dapat meningkatkan termostabilitas protein ${ }^{[17]}$. Indeks alifatik dari suatu protein menunjukkan volume relatif yang ditempati oleh asam amino seperti alanin, valin, isoleusin dan leusin, yang memiliki rantai samping alifatik dalam strukturnya. Indeks alifatik merupakan faktor positif yang dapat meningkatan termostabilitas suatu protein globular [21]. Protein ROR-1 memiliki indeks alifatik sebesar 74,65.

\subsection{Prediksi Struktur Sekunder}

Struktur sekunder protein dapat dianggap sebagai jembatan yang menghubungkan urutan utama protein dan struktur tersier [22]. Struktur sekunder terbentuk karena interaksi yang terjadi antara gugus $\mathrm{C}, \mathrm{O}$, dan $\mathrm{NH}$ pada asam amino dalam rantai polipeptida untuk membentuk alpha helix, $\beta$-sheet, atau random coil dan yang memfasilitasi pelipatan menjadi struktur tiga dimensi [23].

Tabel 2. Komposisi struktur sekunder ROR-1

\begin{tabular}{lcc}
\hline Struktur sekunder & Jumlah & Komposisi \\
\hline Alpha helix & 228 & $24,33 \%$ \\
310 helix & 0 & $0,00 \%$ \\
Pi helix & 0 & $0,00 \%$ \\
Beta bridge & 0 & $0,00 \%$ \\
Extended strand & 133 & $14,19 \%$ \\
Beta turn & 46 & $4,91 \%$ \\
Bend region & 0 & $0,00 \%$ \\
Random coil & 530 & $56,65 \%$ \\
Ambiguous states & 0 & $0,00 \%$ \\
Other states & 0 & $0,00 \%$ \\
\hline
\end{tabular}

Hasil prediksi struktur sekunder yang diperoleh dari server SOPMA, menunjukkan bahwa struktur sekunder ROR-1 didominasi oleh Random coil (56,65\%), alpha helix (24,33\%), Extended strand (14,19\%) dan beta turn (4,49\%). $\%)$. Struktur alpha helix umumnya menggambarkan ciri protein transmembran karena ikatan hidrogen dari struktur alpha helix membentuk backbone molekul, sedangkan rantai samping struktur alpha helix memiliki sifat hidrofobik. Berdasarkan hasil prediksi server Sopma, menunjukkan bahwa protein ROR-1 memiliki struktur alpha helix dengan persentasi kedua terendah, sedangkan struktur yang memiliki persentase paling tinggi yaitu struktur random coil. Kumparan acak atau random coil protein berfungsi dalam fleksibilitas dan perubahan konformasi[24]. Dimana ikatan peptida dalam random coil yang tidak terlibat dalam ikatan intra-protein hidrogen, menjadikan struktur random coil dapat dengan leluasa berinteraksi dengan molekul air, ligan kecil, atau dengan protein yang lain [25]. 


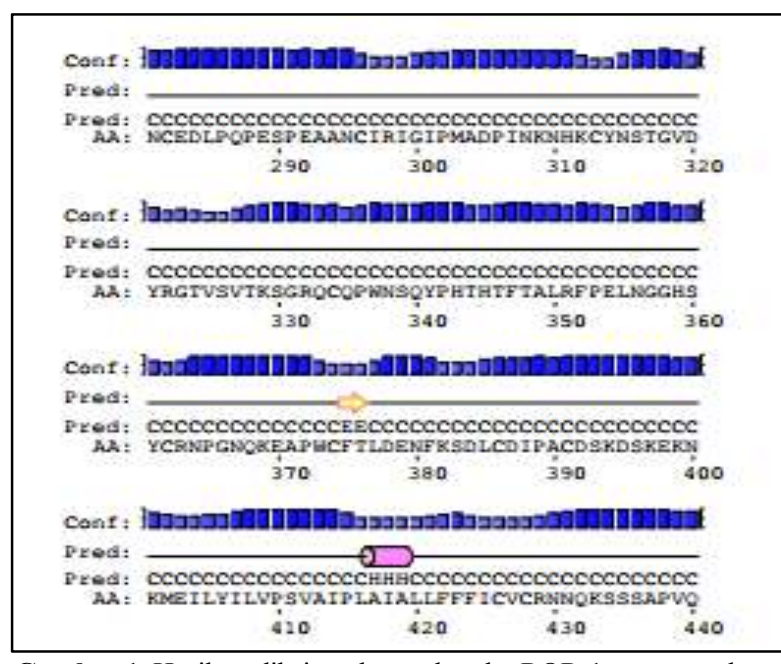

Gambar 1. Hasil prediksi struktur sekunder ROR-1 menggunakan server PSIPRED

\subsection{Prediksi Struktur Tersier}

Hasil BLAST struktur protein yang homolog (template) dengan protein target ROR-1 ditampilkan pada Tabel 4. Prinsip BLAST adalah membandingkan sekuens target dengan setiap sekuens template dari basis data menggunakan perbandingan pasangan sekuens. Keenam template seperti yang terdapat dalam Tabel 4 merupakan template yang telah diketahui struktur tersiernya berdasarkan percobaan eksperimental yang diperoleh dari PDB.

Tabel 3. Hasil Analisis BLAST

\begin{tabular}{ccccc}
\hline Template & $\begin{array}{c}\text { Max } \\
\text { score }\end{array}$ & $\begin{array}{c}\text { Query } \\
\text { cover }\end{array}$ & E value & Identity \\
\hline 3ZZW A & 414 & $30 \%$ & $7 \mathrm{e}-138$ & $68 \%$ \\
4GT4 A & 422 & $32 \%$ & $7 \mathrm{e}-141$ & $66 \%$ \\
4ASZ A, & 255 & $28 \%$ & $2 \mathrm{e}-77$ & $48 \%$ \\
1LUF A, & 278 & $29 \%$ & $2 \mathrm{e}-85$ & $47 \%$ \\
5I8A A & 253 & $28 \%$ & $7 \mathrm{e}-77$ & $47 \%$ \\
\hline
\end{tabular}

Semua template kemudian diolah menggunakan software Modeller, dimana sekuens dari keseluruhan enam template akan disejajarkan dengan sekuens protein target, disesuaikan dengan residu-residu penting yang berperan secara fungsional. Tahap akhir adalah membangun model dari sekuens target yang telah disejajarkan dengan struktur template menghasilkan lima macam model struktur tersier. Kelima hasil prediksi struktur tersier protein ROR-1 kemudian divisualisasikan menggunakan software PyMol seperti yang ditunjukkan pada Tabel 4.

Berdasarkan gambar pada tabel 4, dapat dilihat bahwa kelima hasil prediksi struktur tersier ROR-1 pada dasarnya sama-sama terdiri dari tiga macam struktur sekunder, yaitu $\alpha$-helix, $\beta$-sheet dan random coil. Namun, meskipun tersusun atas struktur sekunder yang sama, namun dapat dilihat bahwa bentuk struktur kelima model tersebut memiliki sedikit perbedaan.

Tabel 4. Visualisasi model struktur tersier ROR-1 menggunakan $P y M o l$

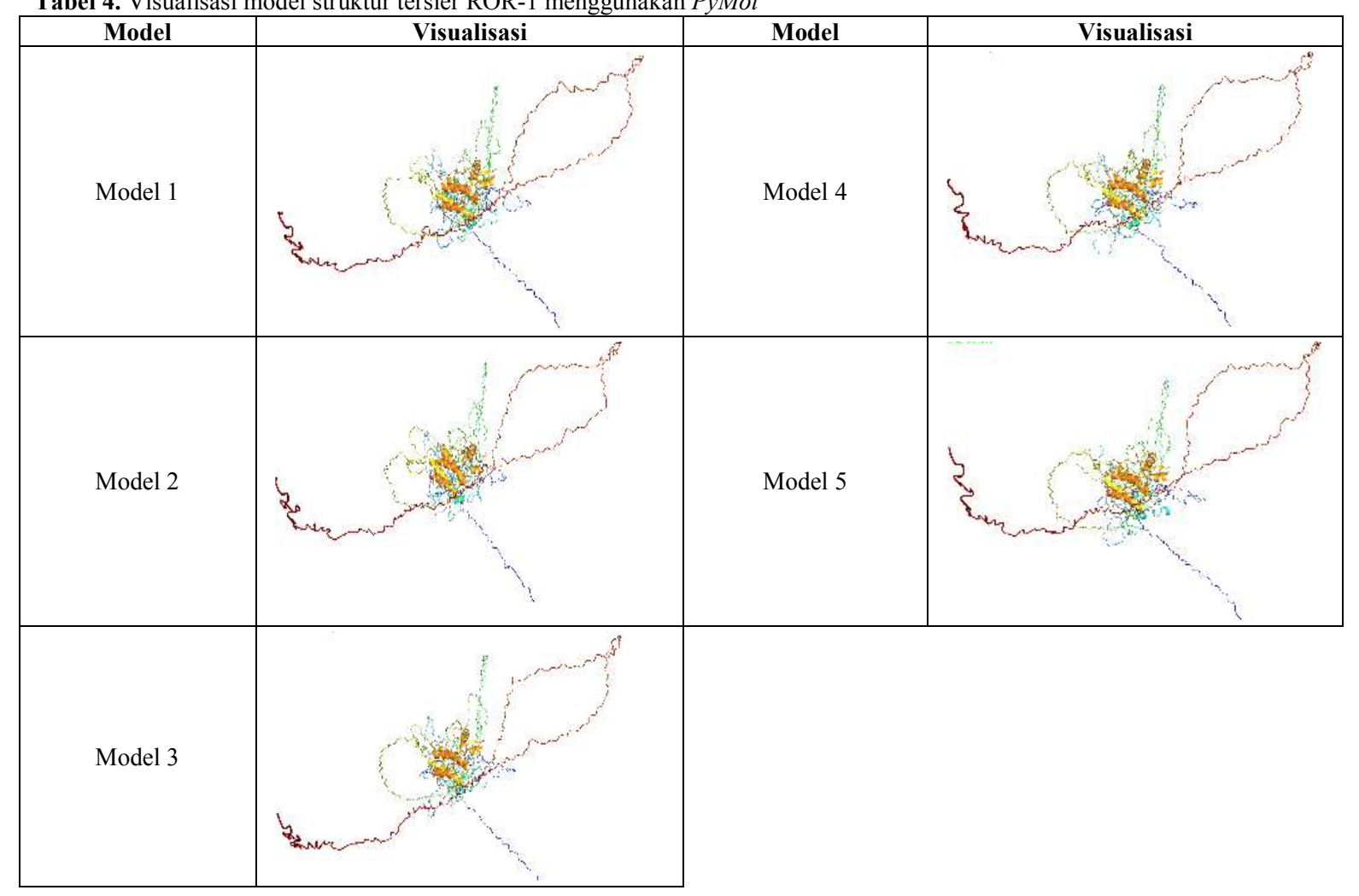




\subsection{Validasi Struktur}

Validasi kelima model struktur protein ROR-1 dapat diketahui dengan menganalisis kualitas stereokimianya menggunakan Procheck berdasarkan analisis plot Ramachandran. Plot Ramachandran akan memvisualisasikan sudut-sudut dihedral $\varphi$ (phi) dan $\psi$ (psi) untuk semua residu asam amino dalam struktur protein sehingga dapat memprediksi konformasi rantai utama polipeptida mana yang secara teoritis memungkinkan dengan melihat distribusi sudut dan memberikan gambaran daerah yang diperbolehkan dan tidak diperbolehkan dari nilai sudut dihedral yang berfungsi sebagai faktor penting dalam penilaian kualitas struktur tiga dimensi protein. Kualitas struktur yang baik dapat dilihat dari persentase residu asam amino yang ditampilkan sebagai titik biru dalam plot Ramachandran yang berada pada most favoured region (daerah yang paling disukai) dan disallowed region (daerah yang tidak diperbolehkan). Hasil analisis plot Ramachandran dari kelima struktur model ROR-1 ditunjukkan pada Tabel 5.

Tabel 5. Hasil Analisis Plot Ramachandran Model Struktur ROR-1

\begin{tabular}{ccccc}
\hline Model & $\begin{array}{c}\text { Most } \\
\text { Favoured } \\
\text { Regions }\end{array}$ & $\begin{array}{c}\text { Additional } \\
\text { Allowed } \\
\text { Regions }\end{array}$ & $\begin{array}{c}\text { Generously } \\
\text { Allowed }\end{array}$ & $\begin{array}{c}\text { Disallowed } \\
\text { Regions }\end{array}$ \\
\hline 1 & $80,1 \%$ & $14,0 \%$ & $3,5 \%$ & $2,4 \%$ \\
2 & $80,1 \%$ & $12,9 \%$ & $3,0 \%$ & $4,0 \%$ \\
3 & $82,0 \%$ & $11,7 \%$ & $3,9 \%$ & $2,5 \%$ \\
4 & $80,3 \%$ & $11,3 \%$ & $5,3 \%$ & $3,1 \%$ \\
5 & $81,6 \%$ & $11,7 \%$ & $3,0 \%$ & $3,8 \%$ \\
\hline
\end{tabular}

Model 3 merupakan struktur yang paling baik. karena memiliki persentase residu asam amino yang paling tinggi pada most favoured region yaitu 82, $0 \%$, dimana kualitas struktur ini dapat dilihat dari persentase residu asam amino yang ditampilkan sebagai titik hitam dalam plot Ramachandran yang berada pada most favoured region (daerah yang paling disukai) dan disallowed region (daerah yang tidak diperbolehkan) yang divisualisasikan

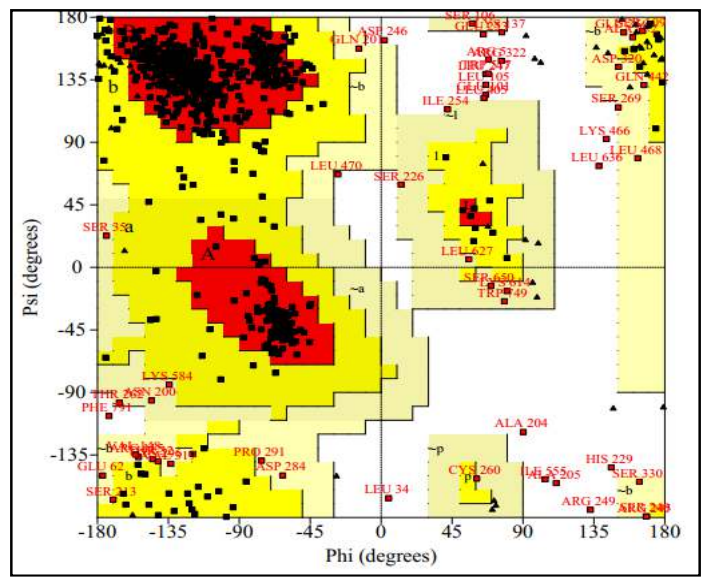

Gambar 3. Plot Ramachandran Model 3.

\section{Kesimpulan}

a. Hasil analisis struktur primer protein ROR-1 meliputi nilai beberapa parameter sifat fisikokimia diantaranya yaitu berat molekul sebesar $104282.62 \mathrm{Da}$, perkiraan waktu paruh pada mamalia retikulosit secara in vitro adalah 30 jam, ragi secara in vivo $>20$ jam dan Escherichia coli secara in vivo $>10$ jam, pI teoritis sebesar 6,76, nilai GRAVY sebesar -0,359, indeks alifatik dengan nilai 74,65 , indeks ketidakstabilan sebesar 54,10 dan komposisi asam amino yang didominasi oleh Serin sebanyak 93 asam amino (9,9\%) dari 937 asam amino penyusun protein ROR-1.

b. Struktur sekunder ROR-1 didominasi oleh Random coil (56,65\%), alpha helix (24,33\%), Extended strand $(14,19$ $\%)$ dan beta turn (4,91\%).

c. Struktur tersier protein ROR-1 dibangun dengan cara membandingkan sekuens asam amino protein ROR-1 dengan kelima template yang tersedia pada Protein Data Bank (PDB) melalui pemodelan homologi yang kemudian diperoleh lima model struktur.

d. Hasil validasi berdasarkan analisis plot Ramachandran diperoleh struktur tersier proten ROR-1 hasil pemodelan yang memiliki kualitas struktur terbaik yaitu, struktur Model 3 dengan jumlah persentase residu asam amino pada most favored region $82 \%$, additional allowed region 11,7\%, generously allowed region $3,9 \%$, disallowed region $2,5 \%$

\section{Daftar Pustaka}

1. Isnani, N., Dyah, A.P., Rizka, A.,Haridini, I.M., 2014, Evaluasi Toksisitas Hematologi Akibat Penggunaan 6Merkaptopurin dalam Fase Pemeliharaan pada Pasien Pediatri Kanker Leukimia Limfoblastik Akut di Rs Kanker Dharmais Jakarta, Media Farmasi, Vol.11 (1).

2. Morrison., Candis., Hesdorffer., Charles, S., 2012., Patients' Guide to Leukemia (Panduan untuk Penderita Leukemia), Penerjemah: Cisya Dewantara, Jakarta: PT Indeks.

3. Arita, M., 2009, Perawatan Pasien Penyakit Dalam, Mitra Cendekia, Yogyakarta.

4. Wirawan, R., 2009, Patogenesis dan Aspek Laboratorium Polisitemia Vera, In: Pendidikan berkesinambungan patologi klinik, Editor: Oesman F, setiabudy RD, Departemen Patologi Klinik Fakultas Kedokteran Univeritas Indonesia, Jakarta.

5. NIH (National Cancer Institute)., Surveillance, Epidemiology, and End Result Program, U.S. Departement of Health and Human, USA.gov, http://seer.cancer.gov.

6. Elter, T M. Hallek, Engert, A., 2006, Fludarabine in chronic lymphocytic leukaemia, Expert Opin. Pharmacother. Vol. 7 (12). 1641-1651.

7. Baskar, A., Wiestner, W.H., Wilson, I., Pastan, C. Rader., 2012, Targeting Malignant B Cells With an Immunotoxin Against ROR1, MAbs 4 (May-June (3)) 349-361.

8. Cui, G.F. Widhopf, L. Chen, L. Rassenti, Z. Wang, S. Ma, dkk., 2013, Preclinical Development of ROR1 Peptide Based Vaccine with Activity Against Chronic Lymphocytic Leukemia in ROR1 Transgenic Mice, Blood, Vol.122 (21) 4174.

9. Reddy, U. R., Phatak, S. \& Pleasure, D., 1996, Human Neural Tissues Express A Truncated Ror1 Receptor Tyrosine Kinase, Lacking Both Extracellular and Transmembrane Domains. Oncogene 13, 1555-1559. 
10. Widhopf, GF., Cui, B., Ghia, EM., dkk., 2014, ROR-1 can Interact with TCL1 and Enhance Leukemogenesis in EmuTCL1 Transgenic Mice, Proc Natl Acad Sci U S A, Vol. 111 (2) : 793-8.

11. Daneshmanesh, A.H., Hojjat-Farsangi, M., Khan, A.S., JeddiTehrani,

M.,

Akhondi M.M., Bayat, A.A., 2012, Monoclonal Antibodies Against ROR-1 Induce Apoptosis of Chronic Lymphocytic Leukemia (CLL) cells, Leukemia, Vol.6 (26) 1348-1355.

12. Yang, J.S. Baskar, K.Y. Kwong, M.G. Kennedy, A. Wiestner, C. Rader., 2011, Therapeutic Potential and Challenges of Targeting Receptor Tyrosine Kinase ROR1 with Monoclonal Antibodies in B-Cell Malignancies, PLoS One, Vol 6 (6) e21018.

13. Roskoski, Jr.B., 2003, STI-571: An Anticancer ProteinTyrosine Kinase Inhibitor, Biochemical and Biophysical Research Communications, Vol. 309 (4).

14. Mulyani, S., dan Karl-Heinz V.P., 2015, Prediksi Model Protein PcpB dari Pentaklorpseudilin Biosintesis Gen Kluster dengan Menggunakan Swiss-Model, Seminar Nasional kimia dan Pendidikan Kimia VII, ISBN : 978-602-73159-0-7.

15. Eswar, N., John B., Mirkovic N., Fiser A., Ilyin VA., Pieper U., Stuart AC., Marti-Renom MA., Madhusudhan MS., Yerkovich B and Sali A., 2003, Tools for Comparative Protein Structure Modeling and Analysis. Nucleic AcidsRes, 31:337580.

16. Toomula, N., Kumar D.S., Kumar V.V.L.P., 2011, Computational Methods for Protein Structure Prediction and Its Application in Drug Design, J.Proteomics Bioinform, 4(12).
17. Walker, J.M., 2005, The Proteomics Protocols Handbook, Humana Press, New Jersey.

18. Thenawidjaja M., Ismayana WT., Retnoningrum DS., 2017, Protein Serial Biokimia Mudah dan Menggugah, Grasindo, Jakarta.

19. Nelson, D.L., dan Cox, M.M., 2007, Lehninger Principles of Biochemistry 4rd Edition, WH Freeman, New York.

20. Guruprasad, K., Reddy, B.V., Pandit, M.W., 1990, Correlation Between Stability of A Protein And Its Dipeptide Composition, A Novel Approach for Predicting In Vivo Stability of A Protein from tts Primary Sequence, Protein Eng. 4, 155-161.

21. Ikai, A., 1980, Thermostability and Aliphatic Index of Globular Proteins. J. Biochem. 88, 1895-1898.

22. Myers, J. K., Oas, T. G., 2001, Preorganized Secondary Structure as an Important Determinant af Fast Protein Folding,Nat. Struct. Mol. Biol., 8.

23. Wang, S., Jian P., Jianzhu M., Jinbo X., 2016, Protein Secondary Structure Prediction Using Deep Convolutional Neural Fields, Scientific Reports, 6.

24. Filiz, E., Koc, I., 2014, In Silico Sequence Analysis and Homology Modeling Of Predicted Beta-Amylase 7-Like Protein In Brachypodium Distachyon L., J. Bio. Sci. Biotech, 3(1).

25. Bauxbaum, E., 2007, Fundamentals of Protein Structure and Function, 2Ed., Springer, London.

26. Putri, S.P., 2018, Pemodelan Homologi Protein Receptor Orphan Receptor-1 (ROR-1) Sebagai Target Terapi Chronic Lymphocytic Leukemia (CLL), Skripsi, Universitas Halu Oleo

C 2019 by the authors; This article is an open access article distributed under the terms and conditions of the Creative Commons Attribution License (http://creativecommons.org/ licenses/by/4.0/) 